\title{
Modeling of sod-podzolic soil fertility indicators optimization in the course of a field experiment
}

\author{
Alexander Ilves ${ }^{1 *}$, Lyudmila Smolina $^{1}$, and Dmitry Danilov ${ }^{1,2}$ \\ ${ }^{1}$ Scientific Research Institute of Agriculture "BELOGORKA”, Belogorka village, Gatchina district, 188338 Leningrad Region, Russia \\ ${ }^{2}$ Saint-Petersburg State Forest Technical University named after S.M. Kirov, 194021 Saint-Petersburg, Russia
}

\begin{abstract}
The formation of primary experimental material was carried out in the form of production seeding and field experiments. Among a large number of indicators assessing certain parameters of soil fertility from the point of view of fertility reproduction, stable characteristics determining agronomic soil value are of the highest importance For sod-podzolic soils, such characteristics are the granulometric composition, the content of organic matter and available forms of mineral nutrition elements, the acidity level. The impact on these indicators determines the effectiveness of soil improvement measures. Based on the generalization of experimental data, on the mathematical and statistical methods, the optimal parameters of these properties for specific crops were determined. To improve and manage soil fertility, it is also necessary to further develop special regulations related to soil enrichment with elements aimed at mineral nutrition of plants and humus. There are complex relationships between the doses of fertilizers and the specific accumulation of the relevant substances, which should be studied in special experiments.
\end{abstract}

\section{Introduction}

Agriculture has now reached such a level that its further development is inevitably connected with forecasting and management of the current soil properties. The analysis of factors influencing soil fertility and agricultural productivity is relevant and in-demand at present for all regions.

Soil fertility determines the yield of crops and stimulates biological, chemical and physical, as well as other processes of soil formation. This is a systemic concept, as the soil is formed in a certain ecological state and is always influenced by the anthropogenic factor.

Currently, there is a new level of research conducted in the field of soil science - a systematic analysis of soil fertility. The various processes occurring in the soil have complex and numerous relationships and therefore this method can be considered as one of the most important and modern of soil research methods. This method is called soil fertility modelling. The main objective of modelling processes related to soil fertility is to identify the most significant factors covering the main features of the research process [1,2].

At present, a large number of practical and theoretical materials allowing application of the methods and principles of system analysis in soil science have been accumulated. By this reasoning, the soil is evaluated as a dynamic quantitative system. In many regions of Europe, studies of the application effect of organic and mineral fertilizers on the fertility of different genesis soils are carried out. New experiments have been initiated in Sweden and Finland in order to study the impact of organic fertilizer on soil fertility $[3,4]$.

In Eastern Europe and the Baltic countries, studies are carried out on model changes in soil complex and organic matter after the introduction of different farming systems and fertilizers [5-9]. The reforms carried out in the 1990-s led to radical changes in the economy of Russia, including market relations formed in agriculture. Insufficient fertilizer application has caused degradation of soil fertility and decreased crop productivity [10].

Agricultural production has become unprofitable and many agricultural enterprises have reduced the area of agricultural land or have completely ceased their production. As a result, large areas of land have been removed from agricultural circulation. For example, only in the North-Western region of Russia, these areas amount to 2.5 million hectares [10].

Podzolic soils in their natural state are of low fertility and degrade relatively rapidly when being removed from agricultural circulation. Therefore, the return of these soils to agricultural use requires a complex of soil improvement measures. At present, agricultural enterprises with the support of regional authorities partially return the land to agricultural circulation, implement farmland reclamation programs.

At the same time, large areas of land in agricultural circulation also have poor fertility parameters from the point of view of the agricultural producer and need to be reclaimed. Soil improvement programs need to be developed on a regulatory basis that characterizes soil fertility, including optimal soil properties, soil fertility

\footnotetext{
* Corresponding author: lenniish@ mail.ru
} 
rates, costs of chemization means in order to achieve them, as well as indicators of soil fertility for different crop yield levels [11-20].

\section{Methods and materials}

The objects of research are the experimental fields of the Leningrad Research Institute of Agriculture Belogorka and the production seeding of the North-Western region of the Russian Federation.

To solve the problem, the method of simultaneous accounting of yield and soil sampling was developed. It is necessary to have at least 50 units of observations in order to obtain reliable mathematical and statistical estimates on the studied parameters. The essence of the method is that soil and crop samples are selected in the areas of cultivated soil bodies during the period of the plant ripening.

The area of the plot is sized from 1 to $4 \mathrm{~m}^{2}$, depending on the crop and objectives of the study. Optimal values of soil properties were determined by the diagram showing the relationship between the crop yield and the tested physico-chemical index.

The assessment of the relationship between generally accepted soil fertility indicators and crop yields is associated with methodological difficulties. In the course of a field experiment, it is difficult to provide significant fluctuations in soil properties in natural conditions. Therefore, the schemes of experiments were developed, when the necessary levels of mobile forms of phosphorus, potassium, humus, and acidity were formed due to high doses of technogenic fertilizers.

Sampling and determination of the soil agrochemical condition were determined according to common methods used in soil complex researches.

The determination of mobile phosphorus and exchange potassium was carried out in a single extract by using the A.T. Kirsanov method. The humus content was determined by the Tyurin method in Nikitin modification. The sum of the exchange bases is determined by the Kappen-Gilkowitz method in Godlin modification, and hydrolytic acidity was determined ionometrically.

The determination of the granulometric composition is carried out with the use of N.A. Kachinsky pipette. In the course of the field multifactor experiment, in order to achieve the planned levels of sod-podzolic light loamy soil reclamation, the following norms of fertilizers were introduced in the experiment variants in different combinations (per $1 \mathrm{ha}$ ): phosphorus fertilizers -250 , $750,2400 \mathrm{~kg} \mathrm{ha}^{-1}$; potash fertilizers - 300, 900, 1950, $3900 \mathrm{~kg} \mathrm{ha}^{-1}$; lowland peat $-240,420,840 \mathrm{t} \mathrm{ha}^{-1}$; lime$7.0 ; 14.5 \mathrm{t} \mathrm{ha}^{-1}$.

Nitrogen fertilizers for crops were introduced as a common background at a rate of N60. The initial level of soil fertility was characterized by the following indicators; humus - $1.6-1.7 \%$; salt $\mathrm{pH} 4.2-4.3$; mobile forms of phosphorus and potassium $-8-10 \mathrm{mg} /$ per $100 \mathrm{~g}$ of soil.

\section{Results and discussion}

The soil environment parameters are crucial for the effective implementation of agricultural technologies [1, $21,22]$. Among a large number of indicators evaluating certain parameters of soil fertility from the point of view of fertility reproduction, the most important are the relatively stable characteristics that determine the agronomic value of soils $[9,10,13]$. Long-term research carried out in field experiments, as well as taking into account crop yields and soil properties in production seeding, allowed establishing the most favorable values of soil properties for obtaining high yields (table 1)

In most cases, agricultural land users can not allow using of large quantities of organic, mineral fertilizers and lime to accelerate the soil improvement according to the economic criteria. The main thing that is dictated by economic conditions is getting the maximum profit from fertilizers and lime, with the obligatory observance of environmental requirements, i.e. good or at least satisfactory product quality, taking into account the minimization of soil and groundwater contamination by residues of fertilizers.

The problem of bringing soil properties to optimal parameters or at least the problem of preservation of fertility level [12-14] remains relevant. The basis of fertility is the processes of accumulation and transformation of substances, energy occurring in soils. Organic matter of soil and fertilizers actively participates in these processes, affects their orientation and intensity [15-16]. In theory, based on the humification coefficient, the application of 100 tonnes of manure per 1 hectare should increase the humus content in the soil by $0.2 \%$. However, according to long-term experiments of the Leningrad Research Institute Belogorka, systematic application of manure in field crop rotation at a dose of 10 $\mathrm{t} \mathrm{ha}^{-1}$ per year for 26 years only slightly increased the content of humus in the soil $(0.15 \%$ according to 400 observations).

The annual introduction of $20 \mathrm{t} \mathrm{ha}^{-1}$ of manure for 17 years (336 observations) increased the humus content only by $0.27 \%$. The fact is that along with the accumulation of humus, the processes of its decomposition are simultaneously strengthened and an unstable balance between these processes is established. According to the results of the field multi-factor experiment after applying the specified rates of fertilizers to the soil, there was certain regularity in the change of soil and agrochemical properties. The average data on the experiment variants are characterized by the long-term dynamics of individual soil properties in the arable layer (tables 2-4).

Long-term observations indicate a low variability of its content in the soil over time in the experiment variants, where different rates of phosphorus fertilizers were introduced. Unlike phosphorus, mobile potassium is subject to a significant change in the experiment variants after the fertilizer application. First, there is a significant accumulation of it in the arable soil layer, and then a sharp decrease. The criterion for assessing the agronomic optimum for the potassium exchange is the 
level of potassium nutrition, providing a high yield of agricultural crops.

Table 1. Favorable intervals of agrochemical properties of sodpodzolic light-loamy and sandy soils.

\begin{tabular}{|c|c|c|c|c|c|}
\hline \multirow[b]{2}{*}{ Cultures } & \multirow{2}{*}{$\begin{array}{c}\text { Planned } \\
\text { harvest, } \\
\text { t/ha }\end{array}$} & \multirow{2}{*}{$\underset{\%}{\text { Humus, }}$} & \multirow[b]{2}{*}{$\mathrm{pH}$} & $\mathrm{P}_{2} \mathrm{O}_{5}$ & $\mathrm{~K}_{2} \mathrm{O}$ \\
\hline & & & & \multicolumn{2}{|c|}{$\begin{array}{c}\text { mg per } 100 \mathrm{~g} \mathrm{o} \\
\text { soil }\end{array}$} \\
\hline Pota & $250-300$ & $3.5-4.0$ & $4.8-5.3$ & $20-25$ & $20-25$ \\
\hline Winter rye & $30-35$ & $2.5-3.5$ & $5.5-6.0$ & $15-25$ & $12-17$ \\
\hline $\mathrm{Wl}$ & $35-$ & \begin{tabular}{|l|}
$3.0-3.5$ \\
\end{tabular} & $6.0-6.8$ & $15-25$ & $12-17$ \\
\hline Barley & $30-35$ & $3.0-4.0$ & $5.6-6.0$ & $15-20$ & $10-15$ \\
\hline $\begin{array}{c}\text { Perennial } \\
\text { grasses } \\
\text { (hay) }\end{array}$ & $70-80$ & $3.0-3.5$ & $5,6-7,0$ & $20-25$ & $15-20$ \\
\hline Red beet & $250-300$ & $3.0-3.5$ & $5,6-7,0$ & $20-25$ & $15-20$ \\
\hline Cabbage & $400-500$ & $4.0-7.0$ & $6.0-6.8$ & $25-30$ & $20-25$ \\
\hline
\end{tabular}

Table 2. Influence of fertilizer rates on changes in the content of mobile forms of phosphorus and potassium

\begin{tabular}{|c|c|c|c|c|c|c|c|c|c|}
\hline \multirow{4}{*}{ 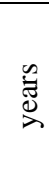 } & \multicolumn{9}{|c|}{ Fertilizer rate, $\mathrm{kg} / \mathrm{ha}$ of active substance } \\
\hline & \multicolumn{4}{|c|}{ Phosphoric } & \multicolumn{5}{|c|}{ Potassium } \\
\hline & 0 & 250 & 750 & 2400 & 0 & 300 & 900 & 1950 & 3900 \\
\hline & \multicolumn{4}{|c|}{$\begin{array}{l}\text { Dynamics } \mathrm{P}_{2} \mathrm{O}_{5} \text {, } \\
\mathrm{mg} / 100 \mathrm{~g} \text { of soil }\end{array}$} & \multicolumn{5}{|c|}{$\begin{array}{c}\text { Dynamics of } \mathrm{K}_{2} \mathrm{O}, \mathrm{mg} / 100 \mathrm{~g} \\
\text { of soil }\end{array}$} \\
\hline 1 & 10 & 13 & 15 & 24 & 12 & 18 & 26 & 49 & 82 \\
\hline 2 & 10 & 13 & 18 & 22 & 11 & 21 & 23 & 30 & 47 \\
\hline 3 & 11 & 14 & 17 & 20 & 11 & 19 & 20 & 33 & 35 \\
\hline 4 & 11 & 16 & 17 & 23 & 14 & 15 & 15 & 22 & 24 \\
\hline 5 & 12 & - & 13 & 25 & 6 & - & 9 & 10 & 10 \\
\hline 6 & 13 & - & 19 & 25 & 7 & - & 7 & 11 & 11 \\
\hline 7 & 13 & - & 13 & 29 & 6 & - & 6 & 4 & 9 \\
\hline 1 & 10 & 13 & 15 & 24 & 12 & 18 & 26 & 49 & 82 \\
\hline
\end{tabular}

Table 3. Influence of low peat application on change of organic matter content

\begin{tabular}{|c|c|c|c|c|}
\hline \multirow{2}{*}{ years } & \multicolumn{4}{|c|}{ Rate of peat application, $\mathrm{tha}^{-1}$} \\
\cline { 2 - 5 } & 0 & 240 & 420 & 840 \\
\cline { 2 - 5 } & \multicolumn{4}{|c|}{ Organic substance, \% } \\
\hline 1 & 1.7 & 2.6 & 3.2 & 4.5 \\
\hline 2 & 1.7 & 2.5 & 2.6 & 4.1 \\
\hline 3 & 1.7 & 2.3 & 2.6 & 3.1 \\
\hline 4 & 1.6 & 2.5 & 2.8 & 3.7 \\
\hline 5 & 1.7 & 2.4 & 2.9 & 3.6 \\
\hline 6 & 1.7 & 2.2 & 2.1 & 3.4 \\
\hline 7 & 1.6 & 2.3 & 2.6 & 3.2 \\
\hline
\end{tabular}

Table 4. Influence of lime application on soil acidity change

\begin{tabular}{|c|c|c|c|}
\hline \multirow{2}{*}{ years } & \multicolumn{3}{|c|}{ Limestone flour application rate, $\mathrm{t} \mathrm{ha}^{-1}$} \\
\cline { 2 - 4 } & 0 & 7.0 & 14.5 \\
\cline { 2 - 4 } & \multicolumn{3}{|c|}{$\mathrm{pH}_{\mathrm{KCl}}$} \\
\hline 1 & 4.2 & 5.5 & 6.3 \\
\hline 2 & 4.2 & 5.3 & 6.2 \\
\hline 3 & 4.3 & 5.2 & 6.2 \\
\hline 4 & 4.3 & 5.6 & 6.3 \\
\hline 5 & 4.2 & 5.2 & 5.6 \\
\hline 6 & 4.2 & 4.9 & 5.8 \\
\hline 7 & 4.3 & 5.1 & 5.4 \\
\hline
\end{tabular}

It seems that the ecological balance of potassium content in the arable layer of sod-podzolic soil of light mechanical composition, according to the data we have received, occurs at its content of up to $6-10 \mathrm{mg} / 100 \mathrm{~g}$ of soil. There is no clear pattern in the change of mobile potassium, as well as phosphorus, depending on other soil properties.

The increase in the content of mobile forms of potassium and phosphorus in the arable soil layer per 1 $\mathrm{mg} / 100 \mathrm{~g}$ of soil required an average introduction of 50$70 \mathrm{~kg}$ of potassium and $120-140 \mathrm{~kg}$ of phosphorus fertilizers respectively.

Planned levels of high humus content in the soil were mainly achieved due to the introduction of high doses of lowland peat. Long-term observations show that the decrease in organic matter is greater than the initial level created.

In the control case, organic matter was stable throughout the observation period in case when no peat was used.

The specific reclaiming efficiency is determined by the dynamics of peat mineralization in the soil. Thus, the increase in organic matter content from $100 \mathrm{t} \mathrm{ha}^{-1}$ of peat for the second year after its introduction amounted to $0.33-0.36 \%$ of different peat rates, and in the future, these values decreased in the process of dynamics (see table 3).

When applying lowland peat $\left(\mathrm{pH}_{\mathrm{KCl}} 6,8-7,0\right)$, the reaction of the soil environment changed. The shift amount of the soil reaction depends on the initial state of the soil. Thus, at the initial $\mathrm{pH}$ ксг -4.2 the change from $100 \mathrm{t} \mathrm{ha}^{-1}$ of peat is $0.29-0.33$ (peat rate $240,420 \mathrm{t}$ $\mathrm{ha}^{-1}$ ), and at $\mathrm{pH}-5.7$ the shift from the same rates amounted to $0.05-0.13$ units of $\mathrm{pH}$ KCl. In the future, the reaction of the soil changed in accordance with the noted dynamics.

Specific cultivating efficiency of lime ( $\mathrm{pH}$ shift from $1 \mathrm{t} \mathrm{ha}^{-1}$ ) depends on the applied rate. When using $7.0 \mathrm{t}$ $\mathrm{ha}^{-1}$ of lime, the soil reaction varied from the initial $\mathrm{pH}$ 4.2 in the arable layer during the year at the rate of $1 \mathrm{t}$ $\mathrm{ha}^{-1}$ to $0.19 \mathrm{pH}$ units $\mathbf{~ K C l}$, and at the lime rate of $14.5 \mathrm{t}$, to 0.14 respectively. The obtained results are consistent with the literature data. In the future, the specific efficiency of lime per $1 \mathrm{t} \mathrm{ha}^{-1}$ decreased significantly.

\section{Conclusion}

Modeling of soil cultivation in the conditions of the field experiment with the use of high fertilizer rates allows determining the nature of changes in soil properties over a long period of time, their long-term dynamics, as well as to establish rates for fertilizer costs in the development of programs for cultivation, reproduction of soil fertility.

It is obvious that agricultural producers can make decisions on the practical implementation of soil cultivation programs after analyzing the cost efficiency of these measures.

The practical essence of establishing optimal values of soil properties consists, first of all, in the fact that they are the theoretical basis for specialization and concentration on cultivating particular crop species, the 
choice of the most rational crop rotation scheme for specific field and farming conditions.

The development of criteria for optimal soil properties, expressed in specific quantitative indicators, is of great importance for scientific forecasting and development of a harvest formation program in specific soil-climatic conditions.

The established criteria of soil properties, optimal parameters serve as target functions in the development of the land reclamation program.

\section{References}

1. R. Seppelt, A. Voinov, Optimization methodology for land use patterns: evaluation based on multiscale habitat pattern comparison Ecolog. modelling 168(6), 217-231 (2003)

2. V.I. Kiryushin, A. L. Ivanov, eds. Agroecological assessment of lands, design of adaptive-landscape systems of agriculture and agrotechnologies 783 (Russ. Acad. of Agricul. Sci., Moscow, 2005)

3. T. Kätterer, O. Andrén, P.E. Jansson, Pedotransfer functions for estimating plantavailable water and bulk density in Swedish agricultural soils Acta Agricult. Scandinavica, Sect. B, Soil \& Plant Sci. 56(4), 263-276 (2006)

4. A. Erling, The farming system component of European agricultural landscapes E. J. of Agronomy 82, Part B, 282-291 (2017)

5. F. Candemir, C. Gülser, Effects of different agricultural wastes on some soil quality indexes at clay and loamy sand fields Communication Soil Sci. and Plant Analyses 42(1), 13-28 (2011)

6. B. Zanten, P.H. Verburg, M. Espinosa et al., European agricultural landscapes, common agricultural policy and ecosystem services: a review Agronomy for Sustainable Development 34(2), 309325 (2014)

7. M. D’Amico, A. Coppola, G. Chinnici, G. Vita, G. Pappalardo, Agricultural systems in the European Union: an analysis of regional differences New Medit. 4, 28-34 (2013)

8. T. Šimon, A. Czakó, Influence of long-term application of organic and inorganic fertilizers on soil properties Plant Soil Environ. 60(7), 314-319 (2014)

9. M.L. Paracchini, T.P. Correia, I. Loupa-Ramos et al., Progress in indicators to assess agricultural landscape valuation: How and what is measured at different levels of governance Land use Policy 53, 71-85 (2016)

10. D. Danilov, A. Ilves, L. Smolina, Criteria for Assessing the Quality of Cultivable Land in Land
Use Optimization Advances in Engineer. Res. 151, 123-128 (2018)

11. M. Benoît, D. Rizzo, E. Marraccini et al., Landscape agronomy: a new field for addressing agricultural landscape dynamics Landsc. Ecol. 27, 1385-1394 (2012)

12. A. Mandal, A.K. Patra, D. Singh, A. Swarup, R.E. Masto, Effect of long-term application of manure and fertilizer on biological and biochemical activities in soil during crop development stages Biores. Technol. 98, 3585-3592 (2007)

13. L.P. Koh, T. Koellner, J. Ghazoul, Transformative optimisation of agricultural land use to meet future food demands Peer. J. 1, e188 (2013)

14. Martin et al., Farming system design to feed the changing world A review Agron. Sustain. Dev. 33(131), 131-149 (2013)

15. K.D. Schneider, R. Paul Voroney, B.J. CadeMenun, D.H. Lynch, Soil phosphorus forms from organic and conventional forage fields soil fertilite plant nutrition Soil Sci. Society of Amerika J. 80(2), 328-340 (2016)

16. A. Granstedt, L. Kjellenberg, Long-Term Field Experiment in Sweden: Effects of Organic and Inorganic Fertilizers on Soil Fertility and Crop Quality In Proc. of an Int. Conf. in Boston, Tufts Univer., Agricult. Production and Nutrition 1-11 (Massachusetts, 19-21 March 1997)

17. M.A. Arshad, Y.K. Soon, R.H. Azooz, N.Z. Lupwayi, S.X. Chang, Soil and crop response to wood ash and lime application in acidic soils Agron. J. 104, 715-721 (2012)

18. R. Lalande, B. Gagnon, I. Royer, Impact of natural or industrial liming materials on soil properties and microbial activity Canad. J. of Soil Sci. 89, 209-222 (2009)

19. I.C. Grieve, D.A. Davidson, P.M.C. Bruneau, Effects of liming on void space and aggregation in an upland grassland soil Geoderma 125, 39-48 (2005)

20. R.J. Haynes, R. Naidu, Influence of lime, fertilizer and manure applications on soil organic matter content and soil physical conditions: a review Nutrient Cycling in Agroecosystems 51, 123-137 (1998)

21. R. Paradeloa, I. Virtob, C. Chenua, Net effect of liming on soil organic carbon stocks: A review Agricult., Ecosyst. \& Environ. 202, 98-107 (1 April 2015)

22. B. Seshadri, M. Zaman, L. Barton et al., Functional Relationships of Soil Acidification, Liming, and Greenhouse Gas Flux 1-71 (2016) 